\title{
HYDROLYSIS OF WHEY PROTEINS BY A Bacillus Licheniformis PROTEASE
}

\author{
HIDRÓLISE DAS PROTEÍNAS DO SORO DE LEITE \\ POR UMA PROTEASE DE \\ Bacillus Licheniformis
}

\author{
Marialice Pinto Coelho Silvestre* \\ Harriman Aley Morais** \\ Viviane Dias Medeiros Silva*** \\ Mauro Ramalho Silva ${ }^{* * * *}$ \\ Márcia Regina Pereira Monteiro ${ }^{* * * *}$ \\ Larissa Leandro Cruz ${ }^{* * * * * *}$
}

\begin{abstract}
Enzymatic hydrolysis of proteins increases the use of whey. In this study, a B. licheniformis protease was used to evaluate the extent of hydrolysis of a whey protein concentrate (WPC) as well as the size distribution of the peptides. Four methods were used to determine the extent of hydrolysis: formol titration, soluble protein content, OPA (orthophytalaldehyde) and osmometry. The fractionation of peptides was performed by size-exclusion high performance liquid chromatography. The soluble protein content method produced the highest value for extent of hydrolysis of the WPC (44.7\%) and the formaldehyde method was considered to be the most suitable for evaluating this parameter. A significant amount of dipeptides and tripeptides $(8.79 \%)$ were produced. A positive and significant correlation was observed between the methods of formaldehyde with OPA $(r=0.9891 ; p=0.0014)$ and OPA with soluble protein content $(r=0.8974$; $p=0.0388)$. The same type of correlation was observed between the extent of hydrolysis obtained by all the four methods with the levels of dipeptides and tripeptides ( $\mathrm{r}=$ from 0.9413 to $0.9485 ; \mathrm{p}=$ from 0.0115 to 0.0169 ) and free amino acids ( $\mathrm{r}=$ from 0.8010 to $0.9197 ; \mathrm{p}=$ from 0.0031 to 0.0437 ).
\end{abstract}

Keywords: Whey. Protein. Enzymatic hydrolysis. Extent of hydrolysis. Peptide fractionation.

\footnotetext{
* Universidade Federal de Minas Gerais

${ }^{* *}$ Universidade Federal dos Vales do Jequitinhonha e Mucuri

*** Edetec Indústria Alimentícia S. A.

${ }^{* * * *}$ Edetec Indústria Alimentícia S. A.

${ }^{* * * * *}$ Universidade Federal de Minas Gerais

******* Universidade Federal de Minas Gerais
} 


\title{
RESUMO
}

\begin{abstract}
A hidrólise enzimática de proteínas contribui para aumentar o aproveitamento do soro de leite. Neste trabalho, empregou-se uma protease de Bacillus licheniformis com este objetivo, avaliando-se a extensão da hidrólise de um concentrado proteico de soro de leite (WPC) e a distribuição de tamanho dos peptídeos. A extensão da hidrólise foi analisada por quatro métodos: titulação com formol, teor de proteína solúvel, OPA (ortoftalaldeído) e osmometria. Conduziu-se o fracionamento dos peptídeos por cromatografia líquida de alto desempenho de exclusão molecular. O maior valor da extensão de hidrólise das proteínas do WPC foi obtido com o método da proteína solúvel $(44,7 \%)$, sendo o do formol considerado como o mais adequado para avaliar este parâmetro. Obteve-se quantidade significativa de die tripeptídeos. Observou-se correlação positiva e significativa entre os métodos do formol com OPA $(\mathrm{r}=0,9891 ; \mathrm{p}=0,0014)$ e OPA com proteína solúvel $(\mathrm{r}=$ 0,$8974 ; p=0,0388$ ). Verificou-se o mesmo tipo de correlação entre a extensão da hidrólise, obtidas pelas quatro metodologias, com o teor de di- e tripeptídeos $(\mathrm{r}=$ de 0,9413 a 0,$9485 ; \mathrm{p}=$ de 0,0115 a 0,0169$)$ e de aminoácidos livres $(\mathrm{r}=\mathrm{de}$ $0,8010$ a 0,$9197 ; p=$ de 0,0031 a 0,0437$)$.
\end{abstract}

Palavras-chave: Soro. Proteína. Hidrólise enzimática. Extensão da hidrólise. Fracionamento de peptídeo.

\section{Introduction}

The enzymatic hydrolysis of proteins is a process that can contribute to increasing the use of whey and consequently reducing environmental pollution. Although whey contains high quality proteins and other important ingredients, most of them are discarded as effluent and this remains one of the most serious problems in the dairy industry in several countries (CARRASCO; GUERRA, 2010). Additionally, this enzymatic process might lead to the improvement of the nutritional, functional, immunological and biological properties of whey proteins (PACHECO; SGARBIERI, 2005; CHEISON et al, 2009). The usefulness of whey in its natural form is limited because it is perishable and its components are highly diluted. As an alternative, a whey derivative can be used, such as whey protein concentrate (WPC), which consists of a product obtained from the separation of whey proteins using a membrane system and which is composed of 35 to $80 \%$ protein (BRANS et al, 2004).

The hydrolyzed proteins obtained from the enzymatic treatment of whey could be used for the development of new food products or dietary supplements. Consequently, a prior characterization of these hydrolyzed proteins is required, including the determination of the extent of hydrolysis and the distribution of peptides according to the chain length (SILVESTRE, 1997; GUADIX et al, 2000; LÉONIL et al, 2000).

The methods for the determination of the extent of hydrolysis are based on varied principles: the determination of the hydrolytic release of nitrogen, which becomes soluble in the presence of a precipitating agent, such as trichloroacetic acid; the determination of free $\alpha$-amino-groups; the titration of protons released after the rupture of peptide bonds; and the measurement of the changes in the freezing point of the protein solution by osmometry (SILVESTRE, 1997, NIELSEN et al, 2001; SPELLMAN et al, 2003).

Although a great number of studies in the literature report the determination of the extent of hydrolysis of whey proteins, only few of them mention the comparison of methods used for assessing this parameter for whey proteins, especially concerning the use of techniques based on different principles. Futhermore, in these studies the comparison was only carried out between methods based on the reaction of $\alpha$-amino groups with either derivatizing agents (NIELSEN et al, 2001) or the $\mathrm{pH}$ stat method (SPELLMAN et al, 2003; CHEISON et al, 2009). It is also worth stating that the evaluation 
of the extent of hydrolysis of whey proteins obtained by the action of a $B$. licheniformis protease was performed for the first time in the current study. As far as the authors know, this is also the first report of a correlation among the four methods used in the present study to determine the extent of hydrolysis of whey proteins obtained by the action of a $B$. licheniformis protease.

The use of hydrolyzed proteins for dietetic purposes requires knowledge of the size distribution of peptides because the length of the peptide chain influences the rate of absorption. Our group has developed a method for fractionating small peptides with molecular masses smaller than 1,000 Da, and this technique was employed in the current study (SILVESTRE et al, 1994a, b). The correlation between the extent of hydrolysis and the size distribution of peptides was established, considering that this kind of study has not previously been conducted.

This research aimed to use a $B$. licheniformis protease to hydrolyze whey proteins and also to analyze the hydrolyzed proteins with regard to the extent of hydrolysis and the size distribution of the peptides.

\section{Materials and Methods 2.1 Materials}

A protease from Bacillus licheniformis (Alcalase ${ }^{\circledR}$, activity $=6.22 \mathrm{U} \mathrm{mL}^{-1}$ ) was kindly provided by Novozymes (Araucaria, PR, Brazil). In this study, the enzyme activity was defined as the amount of enzyme that liberated $1 \mathrm{~g}$ of tyrosine in $1 \mathrm{~min}$ at $37^{\circ} \mathrm{C}$. WPC (Kerrylac 750) in powdered form was kindly provided by Kerry of Brazil Ltd. (Três Corações, MG, Brazil).

The polyvinylidene fluoride membranes used for the filtration of the samples $(0.22 \mu \mathrm{m})$ and solvents $(0.45 \mu \mathrm{m})$ as well as the tangential flow system with a $10 \mathrm{kDa}$ cut-off membrane were purchased from Millipore (São Paulo, SP, Brazil). The Folin-Ciocalteu reagent (code F9252), bovine serum albumin (code A2153), orthophytaldehyde (OPA, code P0657) and 2-mercaptoethanol (code M6250) were purchased from Sigma (São Paulo, SP, Brazil). The formic acid was purchased from Merck (Whitehouse Station,
NJ, USA). All other reagents used in this study were of analytical grade.

The HPLC consisted of one isocratic pump and a UV-Vis detector (1200 Series, Agilent, Santa Clara, CA, USA) coupled to a computer with ChemStation software for LC Systems (Agilent, Santa Clara, CA, USA). A poly (2-hydroxyethylaspartamide)-silica (PHEA) column $(250 \times 9.4 \mathrm{~mm}, 5 \mu \mathrm{m}$ and $200 \AA$ pore size) was used for HPLC. The water for HPLC was purified by passage through a MilliQ water purification system (Millipore, Billerica, MA, USA).

\subsection{Methods}

\subsubsection{Hydrolysis of whey proteins}

A protease from Bacillus licheniformis was used to hydrolyze whey proteins from WPC, and the following reaction times were tested: $1 \mathrm{~h}(\mathrm{P} 1)$, 2h (P2), 3h (P3), 4h (P4) and 5h (P5). The pH (8.0) and temperature $\left(60^{\circ} \mathrm{C}\right)$ values corresponded to the optimal conditions for the enzyme and were provided by the manufacturer. Initially, WPC solutions (10\%, $\mathrm{w} / \mathrm{v}$ ) were prepared, and after adjustment of the $\mathrm{pH}$ to 8.0 with a $3 \mathrm{~mol} \mathrm{~L}^{-1} \mathrm{NaOH}$ solution, the solutions were heated in an oil bath with continuous stirring (stirrer 752A model from Fisatom, São Paulo, SP, Brazil); the enzyme was added in an appropriate quantity to attain an enzyme:substrate ratio of 8.0:100. After having reached the desired time, the hydrolytic reaction was stopped by heating the samples at $75^{\circ} \mathrm{C}$ for $15 \mathrm{sec}$. The hydrolyzed proteins were immediately used for the determination of extent of hydrolysis and then freeze-dried (Freeze Dry System/FreeZone 4.5, model 77500, Labconco, Kansas City, MO, USA) and stored in the freezer $\left(-20^{\circ} \mathrm{C}\right)$ until the characterization of peptide profile.

\subsubsection{Study of the hydrolyzed proteins 2.2.2.1 Evaluation of the extent of hydrolysis}

Among the four methods used to evaluate the extent of hydrolysis, two were based on the determination of $\alpha$-amino nitrogen (formol titration and derivatization with OPA), and the other methods relied on the depression of the freezing point (osmometry) and on the quantification of the soluble protein content after precipitation with trichloroacetic acid. For all methods, a blank using 
unhydrolyzed WPC was submitted to the same procedure as the hydrolyzed samples.

\subsubsection{Titration of amino nitrogen with formaldehyde}

Initially, the titration with formaldehyde, called formol titration, described in the Sorensen method (AOAC, 1995) was used for quantifying the $\alpha$-amino nitrogen (AN). Then, the total nitrogen (TN) was determined by the Kjeldahl method (AOAC, 1995). Finally, the extent of hydrolysis was calculated using the relationship between the $\mathrm{AN}$ and $\mathrm{TN}$ according to equation 1 :

$$
\text { Extent of hydrolysis }(\%)=\frac{\alpha-\text { amino nitrogen }(\mathrm{AN})}{\text { total nitrogen }(\mathrm{TN})} \times 100
$$

\subsubsection{Reaction of amino nitrogen with orthophytaldehyde}

For the reaction of amino nitrogen with orthophytaldehyde (OPA), called derivatization, the method described by Spellman et al (2003) was used with some modifications. A volume of $10 \mu \mathrm{L}$ of the sample was mixed with $3.4 \mathrm{~mL}$ of the OPA reagent, and this mixture was allowed to stand at 25 ${ }^{\circ} \mathrm{C}$ for $2 \mathrm{~min}$. Subsequently, the absorbance was read at $340 \mathrm{~nm}$. The extent of hydrolysis was calculated according to equation 2 :

$$
\text { Extent of hydrolysis }(\%)=\frac{(A B S \times 1.934 \times d)}{c}
$$

Where ABS is the absorbance of the samples, $\mathrm{d}$ is the dilution factor and $\mathrm{c}$ is the protein concentration of the sample $\left(\mathrm{g} \mathrm{L}^{-1}\right)$.

\section{depression \\ 2.2.2.4 Measurement of the freezing point}

The measurement of the freezing point depression of the solution, called osmometry, was conducted by using a micro-osmometer (Precision System 5004, Spectrun, SP, Brazil). For this analysis, a sample volume of $50 \mu \mathrm{L}$ was immediately removed after the hydrolytic reaction and the hydrolysis extent was calculated according to equation 3, proposed by Adler-Nissen (1986):

Extent of hydrolysis $(\%)=\left(\frac{\Delta C}{P \% \times f_{\text {osm }}}\right) \times\left(\frac{1}{\omega}\right) \times\left(\frac{1}{h_{\text {tot }}}\right) \times 100$

Where $\Delta \mathrm{C}$ is the osmolarity (mosmol $\mathrm{L}^{-1}$ ), $\mathrm{P} \%$ is the protein concentration ( $\mathrm{g}$ of protein/ $\mathrm{kg}$ of water), $1 / \omega$ is the calibration factor of the osmometer, which represents the reciprocal of the osmotic coefficient of peptides that is supposed to be a constant value of 1.04 , and $h_{\text {tot }}$ is the total number of peptide bonds in the protein, which is $8.8 \mathrm{mEq} \mathrm{g}^{-1}$ of protein for whey.

\subsubsection{Quantification of the soluble protein}

The method of Hoyle and Merritt (1994), with modifications, was used for determining the extent of hydrolysis, which represented the percentage of solubilized protein in $10 \mathrm{~g} \%$ trichloroacetic acid (TCA) in relation to the total protein content of the sample. Aliquots of $500 \mu \mathrm{L}$ of the hydrolyzed protein were mixed with $500 \mu \mathrm{L}$ of $20 \mathrm{~g} \%$ of TCA solution to obtain the soluble and insoluble fractions in $10 \mathrm{~g} \%$ TCA. After 30 minutes of rest, the mixture was centrifuged at $3000 \times \mathrm{g}$, and the soluble protein content of the supernatant was determined by the method of Lowry et al (1951), modified by Hartree (1972), and the result was expressed as mg of protein. Bovine serum albumin was used as the standard. The extent of hydrolysis was calculated according to equation 4 :

$$
\text { Extent of hydrolysis }(\%)=\frac{\text { soluble protein content in } 10 \mathrm{~g} \% \mathrm{TCA}(\mathrm{mg}) \times 100}{\text { total protein content }(\mathrm{mg})}
$$




\subsubsection{Fractionation and quantification of peptides}

The fractionation of peptides according to chain size was performed by size exclusion (SE) HPLC on a PHEA column, according to the method previously developed by our group (SILVESTRE et al, 1994a), using $0.05 \mathrm{~mol} \mathrm{~L}^{-1}$ formic acid $(\mathrm{pH}$ $2.5)$ as the mobile phase and isocratic conditions at a flow rate of $0.5 \mathrm{~mL} \mathrm{~min}^{-1}$ for $35 \mathrm{~min}$. The samples were dissolved in the mobile phase $(0.1 \% \mathrm{w} / \mathrm{v})$ and filtered through a membrane of $0.22 \mu \mathrm{m} ; 50 \mu \mathrm{L}$ of these solutions were injected onto the column. The mobile phase was filtered through a membrane of $0.45 \mu \mathrm{m}$ and degassed by sonication in an ultrasound bath (USC1400 model, Unique, Santo Amaro, SP, Brazil) for $30 \mathrm{~min}$ before use.

The quantification of the peptides and free amino acids was conducted by using the rapid method of Correct Fraction Area (CFA) that was previously developed by our group (SILVESTRE et al, 1994b). Briefly, five whey standard hydrolysates (two using trypsin and three using pancreatin) were prepared and then fractionated into four fractions by SE-HPLC, as described above. The four fractions were collected (Fraction Collector, CF-1 model, Spectrum Chrom, Houston, TX, USA) and submitted to amino acid analysis following solvent removal (Centrivap, 78100-00D model, Labconco, Kansas City, MO, USA). The calculation of CFA was performed using specific formulas after detection at three wavelengths $(230,280$ and $300 \mathrm{~nm})$ to remove the contribution of aromatic amino acids. A standard curve was drawn to correlate CFA with the amino acid contents of the fractions.

\subsection{Statistical Analysis}

All determinations were performed in three replicates, each measured by triplicate analysis. To verify significant hydrolysis effects among the different treatments, a completely randomized design was adopted in analysis scheme split-plot ( 4 x 6 methods hydrolysis times), and the results were analyzed with SISVAR version 5.3 software (FERREIRA, 2010). A completely randomized experimental design was adopted for the factorial analysis ( 2 x 6 enzyme hydrolysis times) of the peptide profiles, and the results were analyzed with Statistica software (STATSOFT, 2000). The ANOVA and Duncan's test at 5\% probability were used to determine differences between the means of the hydrolysis extent as well as the contents of peptides and free amino acids in the WPC hydrolysates. Significant differences $(p<0.05)$ between the means were evaluated by Duncan's test (PIMENTELGOMES, 2000). The correlations between the extent of hydrolysis obtained by different methods with the contents of the peptides and free amino acids were obtained by Pearson's correlation coefficient (r), which measures the degree of association between two variables, and $\mathrm{p}$ was calculated with t-tests, using BioStat software (AYRES, 2007) for data analysis.

\section{Results and Discussion \\ 3.1 Extent of hydrolysis of proteins}

The extent of hydrolysis obtained by the four methods is shown in Figure 1, where a wide range of values can be noted. The results of the samples were deducted from the values of the blank $(26.6 \%$ for OPA, $8.4 \%$ for soluble protein content, $7.5 \%$ for formol titration and $7.4 \%$ for osmometry). The soluble protein content method gave rise to much higher results than the other methods for all samples and the P5 sample showed the highest value, i.e. $44.7 \%$. The B. licheniformis protease is an endopeptidase of broad specificity (DOUCET et al, 2003) and it may have extensively hydrolyzed the WPC proteins, producing a high content of small peptides that were not precipitated by TCA, and therefore contributed to increase the extent of hydrolysis obtained by this method.

The method that produced the second highest values of extent of hydrolysis was the OPA method (Figure 1). For only one sample (P5), there was no significant difference between the results obtained by the OPA and formaldehyde methods. According to Church et al (1983), some overestimation of the extent of hydrolysis by the OPA method is expected, due to reaction of the $\varepsilon$-amino group of lysine with the derivatizing agent. The OPA method has been used by other authors to estimate the extent of hydrolysis of WPC proteins. Spellman et al (2003) used a B. licheniformis protease at different 
conditions to those used in the present study $(\mathrm{pH} 7$, $50{ }^{\circ} \mathrm{C}, 6 \mathrm{~h}$ ) and reported a maximum of $13.3 \%$. An explanation for the higher results found in the present study (18.4 to $21.1 \%$ ) may be associated with the addition of 2-mercaptoethanol and the preparation of the hydrolysates at $\mathrm{pH} 8.0$, because according to Roth (1971), the reaction of cysteine with OPA can be optimized in the presence of a strong reducing agent, and an alkaline medium contributes to increase the stability of the compound that is formed.

Figure 1 - Extent of hydrolysis of WPC proteins obtained by the action of Bacillus licheniformis protease. Methods of formol titration ( ), derivatization with orthophtalaldhyde ( ), osmometry ( ) and soluble protein content ( ). The results represent the means of triplicate experiments. Different capital letters represent significantly different $(\mathrm{p}<0.05)$ values for a same method and different samples. Small letters represent significantly different $(\mathrm{p}<0.05)$ values for a same sample and different methods.

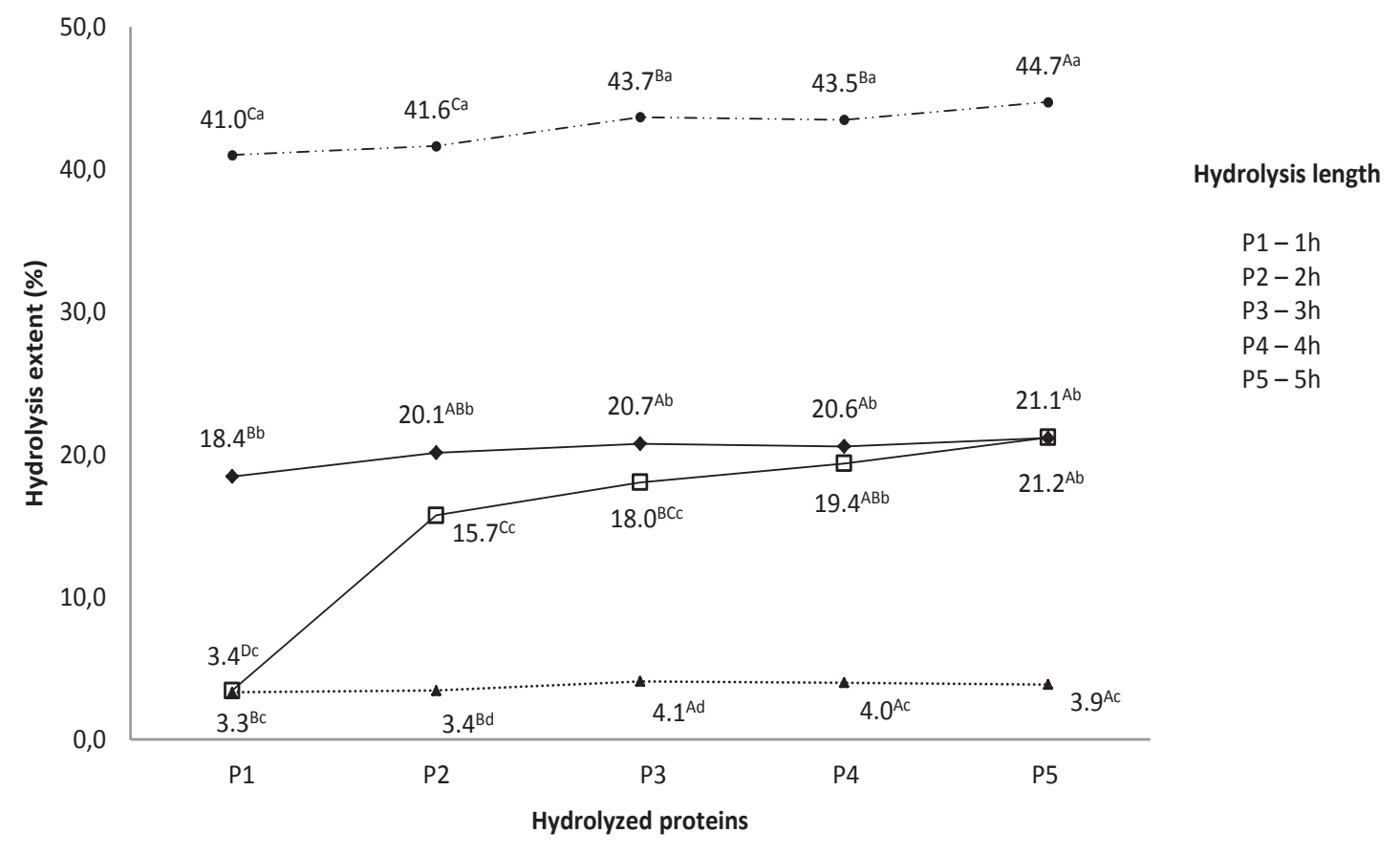

The third highest values for extent of hydrolysis were achieved by using formol titration, where significant differences were observed among the results obtained by this method for two samples (P2 and P3) (Figure 1). The ranking of the formaldehyde method among the four methods that were used could be explained by the increased release of hydrophobic or aromatic residues (GUPTA et al, 2002; RAWLINGS et al, 2010), which may have interfered with the titration of protons released by the addition of formaldehyde (LEVY, 1935) and resulted in an underestimation of the extent of hydrolysis.

Osmometry gave rise to the lowest values for extentofhydrolysis(Figure 1), from3.3 to 4.1\%.TheB. licheniformis protease is an endopeptidase (GUPTA et al, 2002; RAWLINGS et al, 2010) and therefore releases more peptides than free amino acids, thus reducing the extent of hydrolysis determined by osmometry. It is well known that osmometry produces higher values when the number of soluble molecules in the sample is greater, which decreases the freezing point of the solution (WONG; BOYCE, 1988). Also, according to some authors (JU et al, 1995; OTTE et al, 1996; DOUCET et al, 2001), the increase in the number of peptides in a solution can produce aggregation between the peptides, which would result in a gradual increase in the viscosity and turbidity of the samples, interfering with the determination of extent of hydrolysis by osmometry. 
No report was found in the literature describing the use of the methods used here for evaluating the extent of hydrolysis of WPC proteins by a $B$. licheniformis protease action.

\section{hydrolysis \\ 3.2 Hydrolysis length versus extent of}

In general, the hydrolysis length had a weak affect on the extent of hydrolysis of the WPC proteins. In the case of the soluble protein content method, slight increases were observed when the reaction time was increased from $2 \mathrm{~h}$ to $3 \mathrm{~h}$ (from $41.6 \%$ to $43.7 \%$ ) and from $4 \mathrm{~h}$ to $5 \mathrm{~h}$ (from $43.5 \%$ to $44.7 \%$ ). A weak increase was observed for the OPA method when the reaction time was increased from $1 \mathrm{~h}$ to $3 \mathrm{~h}$ (from $18.4 \%$ to $20.1 \%$ ), and the same was observed for the osmometry method when the reaction time was increased from $2 \mathrm{~h}$ to $3 \mathrm{~h}$ (from $3.4 \%$ to $4.1 \%$ ). Only in the case of titration with formaldehyde, did the reaction time produce a sharp increase in the extent of hydrolysis when the reaction time was increased from $1 \mathrm{~h}$ to $2 \mathrm{~h}$ (from $3.4 \%$ to $15.7 \%$ ). From this point forward, the hydrolysis kept increasing at a lower ratio until reaching the maximum value of $21.2 \%$ at $5 \mathrm{~h}$.

It can be inferred that, among the methods tested here, titration with formaldehyde is the most appropriate for evaluating the extent of hydrolysis of WPC proteins hydrolyzed by the B. licheniformis protease because this method exhibited more accentuated differences in the hydrolysis length with the reaction time.

Using different hydrolytic conditions than those used here (E:S 0.25:100; pH 7.0; $50{ }^{\circ} \mathrm{C} ; 6 \mathrm{~h}$ ), Spellman et al (2003) reported a change in the extent of hydrolysis during the first hour of reaction when using the OPA method.

\subsection{Extent of hydrolysis methods: a correlation}

As shown in Table 1, considering that the values found for some correlations were above 0.7 with $\mathrm{p}<0.05$ (SAMPAIO, 2002), it can be inferred that a positive and significant correlation of strong intensity was observed among the following extent of hydrolysis methods: formaldehyde with soluble protein content, OPA with osmometry, and osmometry with soluble protein content.

No literature report on the correlation among the methods used here for evaluating the extent of hydrolysis of WPC was found. However, Spellman et al. (2003) observed a correlation between the extent of hydrolysis values of WPC obtained by the TNBS and $\mathrm{pH}$ stat methods using this same enzyme under different hydrolytic conditions, but no mention was made by these authors about the data used for their statistical analysis.

Table 1 - Correlation among the extent of hydrolysis methods.

\begin{tabular}{l|l|l}
\hline Comparisons & $\mathrm{r}$ & \multicolumn{1}{l}{$\mathrm{p}$} \\
\hline Formaldehyde with OPA & \\
\hline Formaldehyde with osmometry & 0.6492 & 0.0088 \\
\hline Formaldehyde with soluble protein & 0.6641 & 0.0069 \\
\hline $\mathrm{OPA}^{c}$ with osmometry & 0.8245 & 0.0002 \\
\hline OPA $^{c}$ with soluble protein & 0.7650 & 0.0009 \\
\hline Osmometry with soluble protein & 0.5471 & 0.0347 \\
\hline
\end{tabular}

r: correlation; $\mathrm{p}$ : determined by t-Student test with significant differences for $\mathrm{p}<0.05$; OPA: orthophtalaldehyde. 


\subsection{Distribution of peptides according to their size}

In choosing the most appropriate hydrolysates for the development of nutritional supplements for clinical use, previous studies must be considered. During the metabolism of proteins, the first stage of hydrolysis leads to the formation of free amino acids (AA) and small peptides (2-6 AA residues), which can be further hydrolyzed by the brush border peptidases to produce AAs, dipeptides and tripeptides (HINSBERGER; SANDHU, 2004). The AAs may be absorbed either in a free form, by simple or facilitated diffusion (membrane transporters), or as dipeptides and tripeptides (oligopeptide carriers) (GILBERT et al, 2008). Furthermore, according to Frenhani and Burini (1999), the dipeptides and tripeptides are more efficiently absorbed than an equivalent mixture of free amino acids.

The data in Table 2 show that the best peptide distribution was achieved by the P5 sample, followed by the P3 and P4 samples, whose results showed no significant differences. The P5 sample showed $44.61 \%$ of large peptides, $45.40 \%$ of medium peptides, $8.79 \%$ of dipeptides and tripeptides, and $1.20 \%$ of free amino acids. The advantage of P5 over P3 and P4 is associated with its lower large, and higher medium peptide contents.

\subsection{Size distribution of peptides versus extent of hydrolysis}

Table 3 shows a strong positive correlation between the contents of dipeptides and tripeptides with the extent of hydrolysis obtained by all the methods. Additionally, for three of the tested methods (formaldehyde, osmometry and soluble protein content), the same type of correlation occurred between the free amino acid content and the extent of hydrolysis, and a negative correlation was observed between the large peptide content and the extent of hydrolysis.

Considering that, among the fractions that showed a strong positive correlation with the extent of hydrolysis, the dipeptide and tripeptide fraction is the most important in order to evaluate the nutritional value of protein hydrolysates, it can be concluded that all tested methods could be used to screen hydrolyzed WPC proteins obtained by the action of a $B$. licheniformis protease for the preparation of food formulas.

No reports were found in the literature correlating the extent of hydrolysis of WPC hydrolysates with the peptide profile.

Table 2 - Size distribution of peptides and free amino acid content.

\begin{tabular}{cccccc}
\hline $\begin{array}{c}\text { Hydrolyzed } \\
\text { proteins }\end{array}$ & $\begin{array}{c}\text { Reaction } \\
\text { time }(\mathrm{h})\end{array}$ & $\begin{array}{c}\text { Large } \\
\text { peptides }\end{array}$ & $\begin{array}{c}\text { Medium } \\
\text { peptides }^{\mathrm{b}}\end{array}$ & $\begin{array}{c}\text { Dipeptides and } \\
\text { tripeptides }^{\mathrm{c}}\end{array}$ & $\begin{array}{c}\text { Free } \\
\text { amino acids }\end{array}$ \\
\hline P1 & 1 & $63.08^{\mathrm{A}}$ & $36.27^{\mathrm{B}}$ & $0.37^{\mathrm{C}}$ & $0.27^{\mathrm{C}}$ \\
P2 & 2 & $60.26^{\mathrm{A}}$ & $35.24^{\mathrm{B}}$ & $3.90^{\mathrm{B}}$ & $0.60^{\mathrm{B}}$ \\
P3 & 3 & $50.89^{\mathrm{B}}$ & $39.36^{\mathrm{B}}$ & $8.47^{\mathrm{A}}$ & $1.28^{\mathrm{A}}$ \\
P4 & 4 & $53.57^{\mathrm{B}}$ & $36.87^{\mathrm{B}}$ & $8.25^{\mathrm{A}}$ & $1.30^{\mathrm{A}}$ \\
P5 & 5 & $44.61^{\mathrm{C}}$ & $45.40^{\mathrm{A}}$ & $8.79^{\mathrm{A}}$ & $1.20^{\mathrm{A}}$
\end{tabular}

Values are in \% of nmol of the four fractions and represent the means of triplicate. Different numbers represent significantly different $(p<0.05)$ values for different fractions of the same hydrolysate. Large peptides ( $>7$ amino acid residues); medium peptides $(4$ to 7 amino acid residues); dipeptides and tripeptides; free amino acids. Different letters (A, B, C...) represent significantly different $(p<0.05)$ values for the same fraction of different samples. 
Table 3 - Extent of hydrolysis versus size distribution of peptides of hydrolyzed proteins.

\begin{tabular}{cccc}
\hline $\begin{array}{c}\text { Extent of hydrolysis } \\
\text { (method) }\end{array}$ & Chromatographic fractions & $\mathbf{r}$ & $\mathbf{p}$ \\
& Large peptides & -0.7726 & 0.0007 \\
Formaldehyde & Medium peptides & 0.4573 & 0.0865 \\
& Dipeptides and tripeptides & 0.9195 & $<0.0001$ \\
& Free amino acids & 0.8125 & 0.0002 \\
\hline & Large peptides & -0.0606 & 0.0166 \\
OPA $^{c}$ & Medium peptides & 0.3648 & 0.1812 \\
& Dipeptides and tripeptides & 0.7073 & 0.0032 \\
& Free amino acids & 0.6769 & 0.0056 \\
\hline & Large peptides & -0.6135 & 0.0150 \\
Osmometry & Medium peptides & 0.2368 & 0.3955 \\
& Dipeptides and tripeptides & 0.8719 & $<0.0001$ \\
Soluble protein content & Free amino acids & 0.8877 & $<0.0001$ \\
& Large peptides & -0.8683 & $<0.0001$ \\
& Medium peptides & 0.6088 & 0.0160 \\
& Dipeptides and tripeptides & 0.9133 & $<0.0001$ \\
\hline
\end{tabular}

r: correlation; $\mathrm{p}$ : determined by t-Student test with significant differences for

$\mathrm{p}<0.05$; OPA: orthophtalaldehyde; large peptides ( $>7$ amino acid residues); medium peptides (4 to 7 amino acid residues).

\section{Conclusion}

The use of a $B$. licheniformis protease to hydrolyze WPC proteins gave rise to an extent of hydrolysis that ranged from $3.3 \%$ to $44.7 \%$, for the osmometry and soluble protein content methods after $1 \mathrm{~h}$ and $5 \mathrm{~h}$ of reaction, respectively. Formol titration was the most appropriate method for evaluating the extent of hydrolysis of WPC proteins. From the nutritional standpoint, a suitable size peptide distribution of the hydrolyzed proteins was achieved and good correlations were obtained among some extent of hydrolysis methods, as well as between the contents of dipeptides and tripeptides with the extent of hydrolysis obtained by all the methods.

\section{Acknowledgements}

The authors thank CNPq, CAPES and FAPEMIG for their financial support.

\section{References}

ADLER-NISSEN, J. Enzymic hydrolysis of food proteins. New York: Elsevier Applied Science Publishers, 1986.

AOAC - Association of Official Analysis
Chemists. Official methods of analysis of AOAC International. 16th Edn. Arlington: AOAC, 1995.

AYRES, M.; AYRES JR, M.; AYRES, D. L.; SANTOS, A. A. S. BioEstat: aplicações estatísticas nas áreas das ciências biológicas e médicas. Belém, Sociedade Civil Mamirauá: MCTCNPq, 2007. Available at: $<$ http://www.mamiraua. org.br/downloads/programas $>$. Accessed: 15 March 2012.

BRANS, G.; SCHROËN, C. G. P. H.; VAN DER SMAN, R. G. M.; BOOM, R. M. Membrane fractionation of milk: state of the art and challenges. Journal of Membrane Science, v. 243, n. 1-2, p. 263-272, 2004.

CARRASCO, C. A.; GUERRA, M. Lactosuero como fuente de péptidos bioactivos. Anales Venezolanos de Nutrición, v. 23, p. 42-49, 2010.

CHEISON, S. C.; ZHANG, S. B.; WANG, Z.; XU, S. Y. Comparison of a modified spectrophotometric and the $\mathrm{pH}$-stat methods for determination of the degree of hydrolysis of whey proteins hydrolysed in a tangential-flow filter membrane reactor. Food Research International, v. 42, p. 91-97, 2009.

CHURCH, F. C.; SWAISGOOD, H. E.; PORTER, D. H.; CATIGNANI, G. H. Spectrophotometric 
assay using o- phthalaldehyde for determination of proteolysis in milk and isolated milk proteins. Journal of Dairy Science, v. 66, p. 1219-1227, 1983.

DOUCET, D.; OTTER, D. E.; GAUTHIER, S. F.; FOEGEDING, E. A. Enzyme-induced gelation of extensively hydrolyzed whey proteins by Alcalase: peptide identification and determination of enzyme specificity. Journal of Agricultural and Food Chemistry, v. 51, p. 6300-6308, 2003.

DOUCET, D.; GAUTHIER, S. F.; FOEGEDING, E. A. Rheological characterization of a gel formed during extensive enzymatic hydrolysis. Journal of Food Science, v. 66, p. 711-715, 2001.

FERREIRA, D. F. SISVAR versão 5.3 (build 75). Lavras: DEX/UFLA, 2010.

FRENHANI, P. B.; BURINI, R. C. Mecanismos de absorção de aminoácidos e oligopeptídeos: controle e implicações na dietoterapia humana. Arquivos de Gastroenterologia, v. 36, p. 227-237, 1999.

GILBERT, E. R.; WONG, E. A.; WEBB JR, K. E. Peptide absorption and utilization: implications for animal nutrition and health. Journal of Animal Science, v. 86, p. 1493-1501, 2008.

GUADIX, A.; GUADIX, M.; PÁEZ-DUEÑAS, M. P.; GONZÁLEZ-TELLO, P.; CAMACHO, F. Procesos tecnológicos y métodos de control en la hidrólisis de proteínas. Ars Pharmaceutica, v. 41, p. 79-89, 2000.

GUPTA, R.; BEG, Q. K.; LORENZ, P. Bacterial alkaline proteases: molecular approaches and industrial applications. Applied Microbiology and Biotechnology, v. 59, p. 15-32, 2002.

HARTREE, E. F. Determination of protein: a modification of the Lowry method that gives a linear photometric response. Analytical Biochemistry, v. 48, p. 422-427, 1972.

HINSBERGER, A.; SANDHU, B.K. Digestion and absorption. Current Paediatrics, v. 14, p. 605-611, 2004.

HOYLE, N. T.; MERRITT, J. H. Quality of fish protein hydrolysates from herring (Clupea harengus). Journal of Food Science, v. 59, p. 76-79, 1994.

JU, Z. Y.; OTTE, J.; MADSEN, J. S.; QVIST, K. B. Effects of limited proteolysis on gelation and gel properties of whey protein isolate. Journal of Dairy Science, v. 78, p. 2119 2128, 1995.

LÉONIL, J.; GANAIRE, V.; MOLLÉ, D.; PEZENNEC, S.; BOUHALLAB, S. Application of chromatography and mass spectrometry to the characterization of food proteins and derived peptides. Journal of Chromatography A, v. 881, p. 1-21, 2000.
LEVY, M. Equilibria of the basic amino acids in the formol titration. Journal of Biological Chemistry, v. 109, p. 365381, 1935.

LOWRY, O. H.; ROSEBROUGH, N. J.; FARR, A. L.; RANDALL, R. J. Protein measurement with the Folin phenol reagent. Journal of Biological Chemistry, v. 193, p. 265 $275,1951$.

NIELSEN, P. D.; PETERSEN, D.; DAMBMANN, C. Improved method for determining food protein degree of hydrolysis. Journal of Food Science, v. 66, p. 642-646, 2001.

OTTE, J.; JU, Z. Y.; SKRIVER, A.; QVIST, K. B. Effect of limited proteolysis on the microstructure of heat-induced whey proteins. International Dairy Journal, v. 79, p. 782790, 1996.

PACHECO, M. T. B.; SGARBIERI, V. C. Effect of different hydrolysates of whey protein on hepatic glutathione content in mice. Journal of Medicinal Food, v. 8, p. 337-342, 2005.

PIMENTEL-GOMES, F. Course of experimental statistics. 14th Edn. Piracicaba: Nobel, 2000.

RAWLINGS, N. D.; BARRETT, A. J.; BATEMAN, A. MEROPS: the peptidase database. Nucleic Acids Research, v. 38, p. 227-233, 2010.

ROTH, M. Fluorescence reaction for amino acids. Analytical Chemistry, v. 43, p. 880-882, 1971.

SAMPAIO, I. B. M. Estatística aplicada à experimentação animal. 2nd Edn., Belo Horizonte: FEPMVZ, 2002.

SILVESTRE, M. P. C. Review of methods for the analysis of protein hydrolysates. Food Chemistry, v. 60, p. 263-271, 1997.

SILVESTRE, M. P. C.; HAMON, M.; YVON, M. Analyses of protein hydrolysates. 1. Use of poly (2-hydroxyethylaspartamide)-silica column in size-exclusion chromatography for the fractionation of casein hydrolysates. Journal of Agricultural and Food Chemistry, v. 42, p. 2778-2782, 1994a.

SILVESTRE, M. P. C.; HAMON, M.; YVON, M. Analyses of protein hydrolysates. 2. Characterization of casein hydrolysates by a rapid peptide quantification method. Journal of Agricultural and Food Chemistry, v. 42, p. 2783-2789, 1994b.

SPELLMAN, D.; MCEVOY, E.; O'CUINN, G.; FITZGERALD, R. J. Proteinase and exopeptidase hydrolysis of whey protein: comparison of the TNBS, OPA and $\mathrm{pH}$ stat method for quantification of degree of hydrolysis. International Dairy Journal, v. 13, p. 447-453, 2003.

WONG, T. M.; BOYCE, C. O. L. Monitoring proteolysis by osmometry: a rapid method. In: CHERRY J. P.; BARFORD, R. A. (Eds.). Methods for protein analysis, Champaign: American Oil Chemists Society, 1988. 